Research Article

\title{
Study of Grape Polyphenols by Liquid Chromatography-High-Resolution Mass Spectrometry (UHPLC/QTOF) and Suspect Screening Analysis
}

\author{
Riccardo Flamini, ${ }^{1}$ Mirko De Rosso, ${ }^{1}$ and Luigi Bavaresco ${ }^{2}$ \\ ${ }^{1}$ Consiglio per la Ricerca e la Sperimentazione in Agricoltura, Centro di Ricerca per la Viticoltura (CRA-VIT), \\ Laboratorio Chimico, Viale XXVIII Aprile 26, 31015 Conegliano, Italy \\ ${ }^{2}$ Istituto di Frutti-Viticoltura, Università Cattolica S.C., Via Emilia Parmense 84, 29122 Piacenza, Italy
}

Correspondence should be addressed to Riccardo Flamini; riccardo.flamini@entecra.it

Received 17 November 2014; Accepted 7 January 2015

Academic Editor: Antonio Ruiz Medina

Copyright (C) 2015 Riccardo Flamini et al. This is an open access article distributed under the Creative Commons Attribution License, which permits unrestricted use, distribution, and reproduction in any medium, provided the original work is properly cited.

\begin{abstract}
Suspect screening analysis is a targeted metabolomics method in which the identification of compounds relies on specific available information, such as their molecular formula and isotopic pattern. This method, coupled to liquid chromatography-high-resolution mass spectrometry, is effective in the study of grape metabolomics, in particular for characterization of flavonols, stilbene derivatives, and anthocyanins. For identification of compounds expected in the samples, a new database of putative compounds was expressly constructed by using the molecular information on potential metabolites of grape and wine from the literature and other electronic databases. Currently, this database contains around 1,100 compounds. The method allows identification of several hundred grape metabolites with two analyses (positive and negative ionization modes), and performing of data reprocessing using "untargeted" algorithms also provided the identification of some flavonols and resveratrol trimers and tetramers in grape for the first time. This approach can be potentially used in the study of metabolomics of varieties of other plant species.
\end{abstract}

\section{Introduction}

Polyphenols are the principal grape bioactive compounds, which are characterized by antioxidant and peroxyl radical scavenger activity, form complexes with metals ( $\mathrm{Cu}, \mathrm{Fe}$, etc.), and show ability to cross the mammal intestinal wall ([1] and references cited herein).

Flavonols are among the principal classes of bioactive polyphenols and are mainly present in the berry skin. Principals are quercetin, kaempferol and myricetin 3-O-glucoside, and 3-O-glucuronide and rutin. Recently, also isorhamnetin, laricitrin and syringetin 3-O-glucoside, kaempferol and laricitrin 3-O-galactoside, kaempferol-3-O-glucuronide, and quercetin and syringetin 3-O-(6-O-acetyl)glucoside were found in grape $[2,3]$. Quercetin (the main grape flavonol) showed to block the human platelets aggregation and inhibits the cancer cell growth in human tumors ([4] and references cited herein).
Anthocyanins are present in the berry skin and are responsible of red color of grape and wine. In $V$. vinifera grapes, the principals are delphinidin (Dp), cyanidin (Cy), petunidin $(\mathrm{Pt})$, peonidin $(\mathrm{Pn})$ and malvidin $(\mathrm{Mv})$ 3-Omonoglucoside (also pelargonidin 3-O-monoglucoside was found in grape [5]), 3-O-acetylmonoglucoside, 3-O-(6$O$-p-coumaroyl)monoglucoside, and $\mathrm{Mv}-3-\mathrm{O}-(6-\mathrm{O}$-caffeoyl)monoglucoside. Non- $V$. vinifera red grape varieties (hybrid) often also contain diglucoside anthocyanins with a second glucose molecule linked to C-5 hydroxyl group.

Grape anthocyanins are studied for oenological purposes and because they are antioxidant compounds and natural colorants used in nutraceutical, food, and pharmaceutical industry [6-8]. Moreover, they are also studied for chemotaxonomic purposes: for example, the presence of 3,5-Odiglucoside is a marker to distinguish between $V$. vinifera and hybrid grapes, the former being characterized by lower presence, or the absence, of these compounds [9]. 
Another important class of grape polyphenols is the stilbene derivatives, such as cis- and trans-resveratrol $\left(3,5,4^{\prime}\right.$ trihydroxystilbene), resveratrol glucoside ( $Z$ and $E$ piceid), resveratrol dimers (viniferins) and oligomers, piceatannol $\left(3,4,3^{\prime}, 5^{\prime}\right.$-tetrahydroxy-trans-stilbene), and piceatannol glucoside ( $E$ and $Z$ astringin) [11]. In general stilbenes act as phytoalexins in soft tissues, while grapevine synthesizes $\varepsilon$ viniferin, $\delta$-viniferin glucoside, and pallidol in roots, cluster steams, and stems as constitutive compounds [12, 13]; viniferins can also form in grape tissues by oligomerization of trans-resveratrol as active defense against exogenous attacks or be produced from resveratrol by extracellular enzymes released from the pathogen in an attempt to eliminate undesirable toxic compounds $[14,15]$. Also $E$ and $Z \omega$-viniferin and some resveratrol trimers and tetramers, such as ampelopsin $\mathrm{D}$, quadrangularin $\mathrm{A}, \alpha$-viniferin, $E$ - and $Z$-miyabenol $\mathrm{C}$, isohopeaphenol, ampelopsin $\mathrm{H}$, and vaticanol C-like, were found in grapevine leaves, roots, clusters, and stems [16], and $E$-ampelopsin E, E-amurensin B, E-resveratroloside, E-3,5, $4^{\prime}$ trihydroxystilbene 2-C-glucoside, $Z$-ampelopsin E, scirpusin $\mathrm{A}$, and $E$ - and $Z$-vitisin B were found in grapevine canes [17].

Several in vitro studies demonstrated the anticancer, antioxidant, anti-inflammatory, cardioprotective, and platelet aggregation inhibition activity of resveratrol [18-24]. Piceatannol blocks LMP2A, a viral protein-tyrosine kinase implicated in leukemia, non-Hodgkin's lymphoma, and other diseases associated with the Epstein-Barr virus (EBV) $[25,26]$ and showed to act on human melanoma cells [27].

Analytical methods commonly used to study grape polyphenols are performed by reverse-phase high performanceliquid chromatography (HPLC) coupled with spectrophotometry or mass spectrometry (MS) [28, 29]. In general, liquid chromatography/mass spectrometry (LC/MS) and multiple mass spectrometry (MS/MS and $\mathrm{MS}^{n}$ ) are the more effective tool for the structural characterization of these lowmolecular weight (MW) compounds. LC/MS of flavonols in grape extracts was performed in both positive and negative ionization modes $[2,10]$, and analysis of resveratrol and piceatannol is usually performed in negative mode $[30,31]$ and structural characterization of anthocyanins in positive $\mathrm{LC} \mathrm{MS}^{n}$ [32]. Due to the lack of standards commercially available, identification of compounds is also confirmed on the basis of their elution sequence from the column. Moreover, fast methods by direct injection and positive electrospray ionization and multiple mass spectrometry (ESIMS/MS) for structural characterization and semiquantitative profiling on the anthocyanins in grape extracts were developed $[33,34]$.

Collision-induced-dissociation (CID) by using $\mathrm{He}$ as collisional gas is highly effective in differentiation of isobaric anthocyanins: the fragment ions $[\mathrm{M}-162]^{+},[\mathrm{M}-324]^{+}$ (formed by two consecutive losses of sugar residue), $[\mathrm{M}-204]^{+},[\mathrm{M}-308]^{+}$, and $[\mathrm{M}-470]^{+}$(consecutive losses of $p$-coumaroylglucose and glucose) characterize both the monoglucoside and diglucoside compounds. Only in the case of $\mathrm{Mv}-3,5-\mathrm{O}$-diglucoside and $\mathrm{Mv}-3-\mathrm{O}$-(6-caffeoyl)monoglucoside, which have the same nominal mass and aglycone, $\mathrm{MS}^{n}$ is not able to distinguish the two compounds.
"Metabolomics" should provide the comprehensive quantitative and qualitative study of all these grape metabolites. In general, "untargeted metabolomics" methods have high sensitivity, good resolution, and high-throughput capacity and should be able to reveal a great number of candidate biomarker signals in a single run [35]. On the other hand, "targeted metabolomics" is used for the quantitative study of specific compounds but with limited information on the sample metabolome [36, 37].

Suspect screening analysis is a midway approach. The identification method relies on the availability of specific information on the metabolites in the sample-by using high-resolution MS - in particular, their molecular formula and structure [38]. This approach has been applied to the study of grape metabolomics, and a new database (GrapeMetabolomics) has been constructed by including the information on grape and wine metabolites found in the literature and others in electronic databases and the new compounds identified by "untargeted metabolomics" in the samples studied until now. Currently, this database contains more than 1,100 grape and wine putative metabolites with molecular weight between 100 and $1700 \mathrm{Da}$ [39].

This paper describes the study of grape flavonols, anthocyanins, and stilbenes performed by ultrahigh performance-liquid chromatography/quadrupole-time of flight mass spectrometry (UHPLC/QTOF) and suspect screening metabolomics.

\section{Materials and Methods}

2.1. Chemicals and Sample Preparation. Standards of quercetin, myricetin, kaempferol, quercetin glucoside, malvidin-3-O-glucoside, malvidin-3,5-O-diglucoside, and rutin were purchased from Extrasynthese (Genay, France); transresveratrol, piceatannol, E-piceid, and 4',5,7-trihydroxy flavanone were purchased from Sigma-Aldrich (Milan, Italy) and $Z$-piceid was produced by photoisomerization of $E$ isomer with a conversion yield of $83 \%$ by using the same conditions reported for isomerization of trans-resveratrol [28].

Thirty-four hybrid grape varieties (22 red and 12 white obtained by crossing $V$. vinifera, $V$. riparia, $V$. labrusca, $V$. lincecumii, and $V$. rupestris) and $10 \mathrm{~V}$. vinifera grape varieties (Corvina, Enantio, Lambrusco Grasparossa, Montepulciano, Nebbiolo, Nero d'Avola, Primitivo, Raboso Piave, Rossese, and Uva di Troia) were harvested in 2010 and 2012, respectively, at full ripeness (maximum sugar content) from five plants present in the CRA-VIT grapevine germplasm repository (Susegana, Veneto, Italy). For each sample, about 100 berries were picked randomly and immediately frozen at $-20^{\circ} \mathrm{C}$.

For sample preparation, twenty berries were weighed and homogenized using liquid nitrogen and the resulting powder was immediately extracted with pure methanol in ratio $2: 1 \mathrm{v} / \mathrm{w}$ under stirring for $20 \mathrm{~min}$ in the dark. After addition of $200 \mu \mathrm{L}$ of internal standard $4^{\prime}, 5,7$-trihydroxy flavanone $500 \mathrm{mg} / \mathrm{L}$, the sample was centrifuged at $10^{\circ} \mathrm{C}$ for $20 \mathrm{~min}$ by keeping the sample away from light by wrapping with aluminum foil. The solution was filtered with Acrodisc 
GHP $0.22 \mu \mathrm{m}$ filter (Waters) and collected in a vial for LC/MS analysis.

2.2. LC/QTOF Mass Spectrometry. The analytical system used was Agilent UHPLC 1290 Infinity coupled to Agilent 1290 Infinity Autosampler (G4226A) and Agilent 6540 accuratemass Q-TOF mass spectrometer (nominal resolution 40.000) with Jet Stream Ionization source (Agilent Technologies, Santa Clara, CA). Two analyses of each sample were repeated by recording full scan acquisition in both positive and negative ionization modes. After each sample a blank was run. The data acquisition software was Agilent MassHunter version B.04.00 (B4033.2). Chromatography was performed using a Zorbax reverse-phase column (RRHD SB-C18 $3 \times$ $150 \mathrm{~mm}, 1.8 \mu \mathrm{m}$ ) (Agilent Technologies, Santa Clara, CA). The mobile phase was composed of (A) $0.1 \% \mathrm{v} / \mathrm{v}$ aqueous formic acid and (B) $0.1 \% \mathrm{v} / \mathrm{v}$ formic acid in acetonitrile. Gradient elution program: $5 \%$ B isocratic for $8 \mathrm{~min}$, from $5 \%$ to $45 \%$ $\mathrm{B}$ in $10 \mathrm{~min}$, from $45 \%$ to $65 \% \mathrm{~B}$ in $5 \mathrm{~min}$, from $65 \%$ to $90 \%$ in $4 \mathrm{~min}$, and $90 \% \mathrm{~B}$ isocratic for $10 \mathrm{~min}$. Flow rate was $0.4 \mathrm{~mL} / \mathrm{min}$; sample injection was $10 \mu \mathrm{L}$; column temperature was $35^{\circ} \mathrm{C}$.

QTOF conditions are as follows: sheath gas nitrogen $10 \mathrm{~L} / \mathrm{min}$ at $400^{\circ} \mathrm{C}$, drying gas $8 \mathrm{~L} / \mathrm{min}$ at $350^{\circ} \mathrm{C}$, nebulizer pressure $60 \mathrm{psig}$, nozzle voltage $1 \mathrm{kV}$, and capillary voltage $3.5 \mathrm{kV}$. Signals in the $\mathrm{m} / \mathrm{z} 100-1700$ range were recorded. Negative mass calibration was performed with standard mix G1969-85000 (Supelco Inc.) and had residual error for the expected masses between $\pm 0.2 \mathrm{ppm}$. Lock masses are as follows: TFA anion at $m / z 112.9856$ and HP-0921(+formate) at $\mathrm{m} / \mathrm{z} 966.0007$ in negative-ion mode and purine at $\mathrm{m} / \mathrm{z}$ 121.0509 and HP-0921 at $\mathrm{m} / z$ 922.0098 in positive-ion mode. MS/MS conditions are as follows: collision energy between 20 and $60 \mathrm{eV}$ was used to fragment ions in the $\mathrm{m} / z$ 100-1700 range. Acquisition rate was 2 spectra/s.

2.3. Data Analysis. Data processing was performed with Agilent MassHunter Qualitative Analysis software version B.05.00 (5.0.519.0). The database of putative grape and wine metabolites (GrapeMetabolomics) was constructed by including the information on their molecular formulae from the literature and found in electronic databases. "Targeted" data processing was performed by using the algorithm "Find Compounds by Formula" and "untargeted" data reprocessing by the algorithm "Find Compounds by Molecular Feature."

Confidence of the compound identification was based on accurate mass and isotope pattern and was expressed by an "overall identification score" computed as a weighted average of the compound isotopic pattern signals, such as exact masses, relative abundances, and $\mathrm{m} / z$ distances (spacing). Weight parameters were $W_{\text {mass }}=100, W_{\text {abundance }}=60$, and $W_{\text {spacing }}=50$; mass expected data variation $2.0 \mathrm{mDa}+$ $5.6 \mathrm{ppm}$, mass isotope abundance $7.5 \%$, and mass isotope grouping peak spacing tolerance $0.0025 \mathrm{~m} / z+7.0 \mathrm{ppm}$.

\section{Results and Discussion}

3.1. High-Resolution MS and Suspect Screening Analysis. To limit artifacts and possibility of false negative grape extract was prepared by operating in cold condition and with a minimal sample handling. To avoid false positives, a blank was run after each sample and the background was subtracted to the sample chromatogram.

In high-resolution mass spectrometry (HRMS) the compounds are identified by performing the raw data processing using specific algorithms. In this method, molecular formulae (MFs) are calculated by recording the monoisotopic mass and isotopic pattern of the compounds (relative abundances and $m / z$ distances of the signals) [40,41]. Compounds are then identified by searching in the databases of metabolites available [42-44]. Unfortunately, databases specific for grape do not exist and to overcome this problem a method of suspect screening analysis was developed. MFs are calculated by using "targeted" algorithms, which perform deconvolution of the chromatogram and the comparison between the theoretical and experimental isotopic patterns, and the compounds expected in the sample are identified by using a homemade database of putative grape and wine metabolites (GrapeMetabolomics).

After targeted search, the raw data reprocessing by using "untargeted" algorithms provides a list of MF not present in GrapeMetabolomics or with retention times (RT) different from those in the database. When the search in other databases provides the identification of new compounds, with high confident score and compatible with the sample, they are added to the database with the correspondent RT. As a consequence, by increasing the number of samples studied the database itself can be expanded. Identifications are confirmed by multiple mass spectrometry (MS/MS) and accurate mass measurement of fragments [39]. In general, by performing two analyses in positive and negative ionization modes, about 320-450 putative compounds are identified in a grape extract with overall identification score higher than $60 \%$, including anthocyanins, flavones and flavanones, flavanols and procyanidins, stilbenes, phenolic acids, and glycoside aroma precursors, about 30-60 compounds with identification score higher than $99 \%$, and more than hundred higher than $95 \%$. In general, identification score can be affected by low signal intensity (which mainly influenced the score parameters of isotopic patterns) and matrix background in the chromatogram [38]. Since standards of most compounds are not available, identification is performed by overlapping various analytical approaches (accurate mass and isotopic pattern, MS/MS fragmentation, correlation between fragments observed, and putative structure) in agreement with the indications recommended in MS-based metabolomics [45].

3.2. Flavonols. The structures of main flavonols identified in $V$. vinifera grapes are shown in Figure 1. By performing analysis in negative-ion mode, twenty-four glycoside flavonols were identified in some hybrid grape samples (Seibel 19881 and Seyve Villard 12-347), including 4 quercetin, 5 myricetin, 4 kaempferol, 3 isorhamnetin, 2 laricitrin and 3 syringetin derivatives, and 3 dihydroflavonols [10].

Figure 2 shows the overlapped extracted ion chromatograms (EIC) of the $[\mathrm{M}-\mathrm{H}]^{-}$ion signals recorded in the analysis of Seyve Villard 12-347 sample. Compounds 
<smiles>[R]c1c(-c2ccc(O)cc2)oc2cc(O)cc(O)c2c1=O</smiles><smiles>[R]Oc1c(-c2cc(O)c(O)c(OC)c2)oc2cc(O)cc(O)c2c1=O</smiles><smiles>[R]Oc1c(-c2ccc(O)c(O)c2)oc2cc(O)cc(O)c2c1=O</smiles><smiles></smiles><smiles>COc1cc(-c2oc3cc(O)cc(O)c3c(=O)c2O)ccc1O</smiles><smiles>[R20]c1c(-c2cc(O)c(O)c(OC)c2)oc2cc(O)cc(O)c2c1=O</smiles><smiles>[R]OC1C(=O)c2c(O)cc(O)cc2OC1c1cc([R])c(O)c([R])c1</smiles>

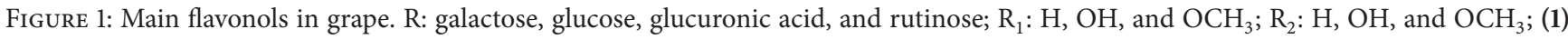
kaempferol, (2) quercetin, (3) myricetin, (4) isorhamnetin, (5) laricitrin, (6) syringetin, and (7) dihydroflavonol.

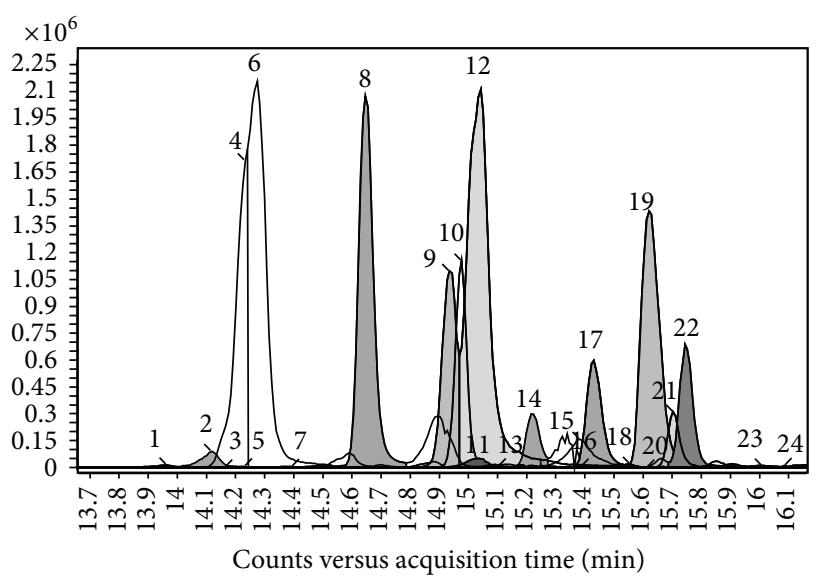

FIGURE 2: Overlapping of the extracted ion chromatograms (EIC) of $[\mathrm{M}-\mathrm{H}]^{-}$ion signals of glycoside flavonols identified in UHPLC/QTOF analysis of hybrid grape Seyve Villard 12-347.

identified are listed in Table 1 with their experimental [M-H] $]^{-}$ ions.

Flavonols were identified with an error mass lower than 3 ppm and with identification score higher than $90 \%$. Lower overall identification scores were found for kaempferol galactoside, kaempferol glucuronide, and dihydrokaempferol rhamnoside, probably due to the low signals intensity [39].

Four compounds were identified in grape for the first time: two myricetin derivatives with nominal mass at $\mathrm{m} / \mathrm{z}$ 656 and $m / z 642$, respectively, a syringetin derivative at $m / z$ 670 and an isorhamnetin derivative at $\mathrm{m} / z$ 624. Identification was confirmed by accurate MS/MS: all compounds showed the aglycone fragment and a aglycone-sugar fragment was observed for some of them. New glycoside flavonols identified were myricetin hexoside-glucuronide, a myricetin $O$ di-hexoside, a syringetin $O$-di-hexoside, and isorhamnetin rutinoside.
3.3. Anthocyanins. Figure 3 shows the structures of principal anthocyanins identified in $V$. vinifera grapes. Highly selective and sensitive analysis performed in positive ionization mode allowed the identification of twenty-eight different anthocyanins in some hybrid grapes. Figure 4 shows the overlapped extracted ion chromatograms of $\mathrm{M}^{+\bullet}$ anthocyanin signals recorded in the analysis of Clinton grape ( $V$. labrusca $\times$ V. riparia). Compounds identified are listed in Table 2.

If some isobaric anthocyanins overlap in the chromatogram they can be identified by using a MS system of at least 30.000 resolution. In particular, Cy-3,5-O-diglucoside $\left(\mathrm{C}_{27} \mathrm{H}_{31} \mathrm{O}_{16}\right.$, MW 611.1612) and Dp-3-O-(6-O-p-coumaroyl)monoglucoside $\left(\mathrm{C}_{30} \mathrm{H}_{27} \mathrm{O}_{14}\right.$, MW 611.1401), Pn-3,5-Odiglucoside $\left(\mathrm{C}_{28} \mathrm{H}_{33} \mathrm{O}_{16}, \mathrm{MW} 625.1769\right)$ and Pt-3-O-(6-O-pcoumaroyl)monoglucoside $\left(\mathrm{C}_{31} \mathrm{H}_{29} \mathrm{O}_{14}\right.$, MW 625.1557), Mv3,5-O-diglucoside $\left(\mathrm{C}_{29} \mathrm{H}_{35} \mathrm{O}_{17}, \mathrm{MW}\right.$ 655.1874), and $\mathrm{Mv}-3$ $\mathrm{O}$-(6-O-caffeoyl)monoglucoside $\left(\mathrm{C}_{32} \mathrm{H}_{31} \mathrm{O}_{15}, \mathrm{MW}\right.$ 655.1663) can be present in grape.

3.4. Stilbenes. Principal stilbenes previously identified in vine tissues (leaves, roots, clusters, stems, and canes) are shown in Figure 5. By performing negative-ion analysis of Primitivo grape extract, seventeen stilbene derivatives were identified (Table 3) [39]. Figure 6 shows the EICs of their $[\mathrm{M}-\mathrm{H}]^{-}$ signals.

The overall identification scores (ID scores) ranged between 98.1\% (for a resveratrol dimer) and 99.8\% (cispiceid). Untargeted data processing allowed the identification of some resveratrol trimers and tetramers which were found in grape for the first time. Since several isomeric stilbene derivatives may be present in grape and MS cannot distinguish among them, tentative assignment was based on their column elution sequence and comparison with data from the literature [16, 46-59].

Precursor ions at $\mathrm{m} / z 679.197$ were identified as $E$ miyabenol $\mathrm{C}$ and $Z$-miyabenol $\mathrm{C}$, two resveratrol trimers previously found in $V$. vinifera leaves but not reported in grapes or wines $[16,52]$. Also two resveratrol tetramers with 
TABLE 1: Glycoside flavonol [M-H] $]^{-}$ions identified in hybrid grapes Seibel 19881 and Seyve Villard 12-347. Identification scores calculated with respect to the theoretical mass are reported. Numbers correspond to the peaks of chromatogram in Figure 2 (adapted from de Rosso et al., $2014[10])$.

\begin{tabular}{|c|c|c|c|c|c|c|}
\hline \multirow[b]{2}{*}{ Peak } & \multirow[b]{2}{*}{ Flavonols } & \multirow[b]{2}{*}{ Formula } & \multicolumn{4}{|c|}{$[\mathrm{M}-\mathrm{H}]^{-}$} \\
\hline & & & Rt (min) & $\begin{array}{l}\text { Experimental } \\
\qquad \mathrm{m} / z\end{array}$ & $\begin{array}{c}\text { Theoretical } \\
\mathrm{m} / \mathrm{z}\end{array}$ & Error (ppm) \\
\hline 1 & Syringetin $O$-di-hexoside & $\mathrm{C}_{29} \mathrm{H}_{34} \mathrm{O}_{18}$ & 14.00 & 669.1684 & 669.1672 & 1.7 \\
\hline 2 & Myricetin $O$-di-hexoside & $\mathrm{C}_{27} \mathrm{H}_{30} \mathrm{O}_{18}$ & 14.15 & 641.1373 & 641.1359 & 2.1 \\
\hline 3 & Myricetin hexoside-glucuronide & $\mathrm{C}_{27} \mathrm{H}_{28} \mathrm{O}_{19}$ & 14.16 & 655.1169 & 655.1152 & 2.5 \\
\hline 4 & Myricetin 3-O-galactoside & $\mathrm{C}_{21} \mathrm{H}_{20} \mathrm{O}_{13}$ & 14.26 & 479.0839 & 479.0831 & 2.0 \\
\hline 5 & Myricetin 3-O-glucuronide & $\mathrm{C}_{21} \mathrm{H}_{18} \mathrm{O}_{14}$ & 14.26 & 493.0635 & 493.0624 & 2.5 \\
\hline 6 & Myricetin 3-O-glucoside & $\mathrm{C}_{21} \mathrm{H}_{20} \mathrm{O}_{13}$ & 14.31 & 479.0844 & 479.0831 & 2.9 \\
\hline 7 & Dihydroquercetin 3-O-hexoside & $\mathrm{C}_{21} \mathrm{H}_{22} \mathrm{O}_{12}$ & 14.41 & 465.1046 & 465.1038 & 1.7 \\
\hline 8 & Rutin & $\mathrm{C}_{27} \mathrm{H}_{30} \mathrm{O}_{16}$ & 14.68 & 609.1471 & 609.1461 & 1.6 \\
\hline 9 & Quercetin 3-O-galactoside & $\mathrm{C}_{21} \mathrm{H}_{20} \mathrm{O}_{12}$ & 15.00 & 463.0894 & 463.0882 & 2.8 \\
\hline 10 & Quercetin 3-O-glucuronide & $\mathrm{C}_{21} \mathrm{H}_{18} \mathrm{O}_{13}$ & 15.02 & 477.0687 & 477.0675 & 2.6 \\
\hline 11 & Laricitrin 3-O-hexoside & $\mathrm{C}_{22} \mathrm{H}_{22} \mathrm{O}_{13}$ & 15.06 & 493.0998 & 493.0988 & 2.1 \\
\hline 12 & Quercetin 3-O-glucoside & $\mathrm{C}_{21} \mathrm{H}_{20} \mathrm{O}_{12}$ & 15.06 & 463.0895 & 463.0882 & 2.9 \\
\hline 13 & Laricitrin 3-O-glucuronide & $\mathrm{C}_{22} \mathrm{H}_{20} \mathrm{O}_{14}$ & 15.11 & 507.0789 & 507.0780 & 1.4 \\
\hline 14 & Kaempferol O-rhamnosyl-hexoside & $\mathrm{C}_{27} \mathrm{H}_{30} \mathrm{O}_{15}$ & 15.25 & 593.1518 & 593.1512 & 1.0 \\
\hline 15 & Dihydroquercetin 3-O-rhamnoside & $\mathrm{C}_{21} \mathrm{H}_{22} \mathrm{O}_{11}$ & 15.34 & 449.1097 & 449.1089 & 1.8 \\
\hline 16 & Isorhamnetin $O$-rhamnosyl-hexoside & $\mathrm{C}_{28} \mathrm{H}_{32} \mathrm{O}_{16}$ & 15.37 & 623.1603 & 623.1618 & -2.4 \\
\hline 17 & Kaempferol 3-O-galactoside & $\mathrm{C}_{21} \mathrm{H}_{20} \mathrm{O}_{11}$ & 15.47 & 447.0938 & 447.0933 & 1.2 \\
\hline 18 & Syringetin 3-O-galactoside & $\mathrm{C}_{23} \mathrm{H}_{24} \mathrm{O}_{13}$ & 15.58 & 507.1147 & 507.1144 & 0.3 \\
\hline 19 & Kaempferol 3-O-glucoside & $\mathrm{C}_{21} \mathrm{H}_{20} \mathrm{O}_{11}$ & 15.65 & 447.0943 & 447.0933 & 2.3 \\
\hline 20 & Kaempferol 3-O-glucuronide & $\mathrm{C}_{21} \mathrm{H}_{18} \mathrm{O}_{12}$ & 15.66 & 461.0730 & 461.0725 & 1.0 \\
\hline 21 & Syringetin 3-O-glucoside & $\mathrm{C}_{23} \mathrm{H}_{24} \mathrm{O}_{13}$ & 15.73 & 507.1156 & 507.1144 & 2.6 \\
\hline 22 & Isorhamnetin 3-O-hexoside & $\mathrm{C}_{22} \mathrm{H}_{22} \mathrm{O}_{12}$ & 15.78 & 477.1045 & 477.1038 & 1.3 \\
\hline 23 & Isorhamnetin 3-O-glucuronide & $\mathrm{C}_{22} \mathrm{H}_{20} \mathrm{O}_{13}$ & 16.00 & 491.0838 & 491.0831 & 1.2 \\
\hline 24 & Dihydrokaempferol 3-O-rhamnoside & $\mathrm{C}_{21} \mathrm{H}_{22} \mathrm{O}_{10}$ & 16.08 & 433.1147 & 433.1140 & 1.6 \\
\hline
\end{tabular}<smiles>OCC(O)C1C(O)OCCOC(Oc2cc3c(O)cc(O)cc3[o+]c2-c2ccc(O)cc2)C(O)C1O</smiles>

1<smiles>COc1cc(-c2cc(-c3cc(O)c(O)c(O)c3)c(OCC(O)C3COCC(O)C(O)C3O)o2)c2cc(O)cc(O)c2c1</smiles><smiles>Oc1cc(O)c2cc(OC3OCC(O)C(O)C(O)C(O)O3)c(-c3ccc(O)c(O)c3)cc2c1</smiles>

2<smiles>COc1cc(-c2[o+]c3cc(O)cc(O)c3cc2OCC(O)C(O)C(O)CO)ccc1O</smiles>

3<smiles>Oc1cc(O)c2cc(OCC(O)C3OC(O)C(O)C(O)C3O)c(-c3cc(O)c(O)c(O)c3)cc2c1</smiles>

4

FIGURE 3: Principal grape anthocyanins. R: $\mathrm{H}$, acetyl, p-coumaroyl, and caffeoyl; $\mathrm{R}_{1}: \mathrm{H}, \mathrm{OH}$, and $\mathrm{OCH}_{3} ; \mathrm{R}_{2}: \mathrm{H}, \mathrm{OH}$ and $\mathrm{OCH}$; (1) pelargonidin-3-O-glucoside, (2) cyanidin-3-O-glucoside, (3) peonidin-3-O-glucoside, (4) delphinidin-3-O-glucoside, (5) petunidin-3-Oglucoside, (6) malvidin-3-O-glucoside, and (7) anthocyanidin-3,5-O-diglucoside. 
TABLE 2: Anthocyanin $\mathrm{M}^{+\bullet}$ ions identified in Clinton grape extract. Identification scores calculated with respect to the theoretical mass are reported. Numbers correspond to the peaks of chromatogram in Figure 4.

\begin{tabular}{|c|c|c|c|c|c|}
\hline \multirow[b]{2}{*}{ Peak } & \multirow[b]{2}{*}{ Anthocyanins } & \multirow[b]{2}{*}{ Formula } & \multicolumn{3}{|c|}{$\mathrm{M}^{+\bullet}$} \\
\hline & & & $\operatorname{Rt}(\min )$ & $\begin{array}{l}\text { Experimental } \\
\qquad \mathrm{m} / \mathrm{z}\end{array}$ & Error (ppm) \\
\hline 1 & Cyanidin-3,5-O-diglucoside & $\mathrm{C}_{27} \mathrm{H}_{31} \mathrm{O}_{16}$ & 11.24 & 611.1612 & 1.1 \\
\hline 2 & Petunidin-3,5-O-diglucoside & $\mathrm{C}_{28} \mathrm{H}_{33} \mathrm{O}_{17}$ & 11.52 & 641.1718 & 1.0 \\
\hline 3 & Delphinidin-3-O-monoglucoside & $\mathrm{C}_{21} \mathrm{H}_{21} \mathrm{O}_{12}$ & 12.03 & 465.1033 & 4.0 \\
\hline 4 & Peonidin-3,5-O-diglucoside & $\mathrm{C}_{28} \mathrm{H}_{33} \mathrm{O}_{16}$ & 12.14 & 625.1769 & 1.1 \\
\hline 5 & Delphinidin acetyldiglucoside & $\mathrm{C}_{29} \mathrm{H}_{33} \mathrm{O}_{18}$ & 12.16 & 669.1667 & -0.1 \\
\hline 6 & Malvidin-3,5-O-diglucoside & $\mathrm{C}_{29} \mathrm{H}_{35} \mathrm{O}_{17}$ & 12.24 & 655.1874 & 1.2 \\
\hline 7 & Cyanidin-3-O-monoglucoside & $\mathrm{C}_{21} \mathrm{H}_{21} \mathrm{O}_{11}$ & 12.57 & 449.1084 & 1.2 \\
\hline 8 & Petunidin-3-O-monoglucoside & $\mathrm{C}_{22} \mathrm{H}_{23} \mathrm{O}_{12}$ & 12.74 & 479.1190 & 1.7 \\
\hline 9 & Peonidin-3-O-monoglucoside & $\mathrm{C}_{22} \mathrm{H}_{23} \mathrm{O}_{11}$ & 13.12 & 463.1240 & -2.0 \\
\hline 10 & Malvidin-3-O-monoglucoside & $\mathrm{C}_{23} \mathrm{H}_{25} \mathrm{O}_{12}$ & 13.27 & 493.1346 & 1.6 \\
\hline 11 & Delphinidin-3-O-acetylmonoglucoside & $\mathrm{C}_{23} \mathrm{H}_{23} \mathrm{O}_{13}$ & 13.59 & 507.1139 & 0.8 \\
\hline 12 & Petunidin caffeoyl diglucoside & $\mathrm{C}_{37} \mathrm{H}_{39} \mathrm{O}_{20}$ & 13.87 & 803.2035 & -2.2 \\
\hline 13 & Delphinidin $p$-coumaroyldiglucoside & $\mathrm{C}_{36} \mathrm{H}_{37} \mathrm{O}_{19}$ & 13.91 & 773.1929 & 1.1 \\
\hline 14 & Petunidin-3-O-acetylmonoglucoside & $\mathrm{C}_{24} \mathrm{H}_{25} \mathrm{O}_{13}$ & 14.14 & 521.1295 & 1.1 \\
\hline 15 & Delphinidin-3-O-caffeoylmonoglucoside & $\mathrm{C}_{30} \mathrm{H}_{27} \mathrm{O}_{15}$ & 14.18 & 627.1350 & 1.3 \\
\hline 16 & Petunidin $p$-coumaryldiglucoside & $\mathrm{C}_{37} \mathrm{H}_{39} \mathrm{O}_{19}$ & 14.36 & 787.2086 & 1.1 \\
\hline 17 & Cyanidin $p$-coumaryldiglucoside & $\mathrm{C}_{36} \mathrm{H}_{37} \mathrm{O}_{18}$ & 14.36 & 757.1980 & 1.0 \\
\hline 18 & Malvidin-3-O-acetylmonoglucoside & $\mathrm{C}_{25} \mathrm{H}_{27} \mathrm{O}_{13}$ & 14.64 & 535.1452 & 1.8 \\
\hline 19 & Peonidin-3-O-acetylmonoglucoside & $\mathrm{C}_{24} \mathrm{H}_{25} \mathrm{O}_{12}$ & 14.65 & 505.1346 & -1.6 \\
\hline 20 & Petunidin-3-O-caffeoylmonoglucoside & $\mathrm{C}_{31} \mathrm{H}_{29} \mathrm{O}_{15}$ & 14.65 & 641.1506 & 1.8 \\
\hline 21 & Malvidin $p$-coumaryldiglucoside & $\mathrm{C}_{38} \mathrm{H}_{41} \mathrm{O}_{19}$ & 14.60 & 801.2242 & -0.8 \\
\hline 22 & Delphinidin-3-O-p-coumarylmonoglucoside & $\mathrm{C}_{30} \mathrm{H}_{27} \mathrm{O}_{14}$ & 14.82 & 611.1401 & 2.0 \\
\hline 23 & Peonidin $p$-coumaryldiglucoside & $\mathrm{C}_{37} \mathrm{H}_{39} \mathrm{O}_{18}$ & 14.85 & 771.2136 & -0.8 \\
\hline 24 & Malvidin-3-O-caffeoylmonoglucoside & $\mathrm{C}_{31} \mathrm{H}_{31} \mathrm{O}_{15}$ & 15.14 & 655.1663 & -3.2 \\
\hline 25 & Cyanidin-3-O-p-coumarylmonoglucoside & $\mathrm{C}_{30} \mathrm{H}_{27} \mathrm{O}_{13}$ & 15.24 & 595.1452 & 1.0 \\
\hline 26 & Petunidin-3-O-p-coumarylmonoglucoside & $\mathrm{C}_{31} \mathrm{H}_{29} \mathrm{O}_{14}$ & 15.30 & 625.1557 & 1.1 \\
\hline 27 & Malvidin-3-O- $p$-coumarylmonoglucoside & $\mathrm{C}_{32} \mathrm{H}_{31} \mathrm{O}_{14}$ & 15.77 & 639.1714 & 1.3 \\
\hline 28 & Peonidin-3-O-p-coumarylmonoglucoside & $\mathrm{C}_{31} \mathrm{H}_{29} \mathrm{O}_{13}$ & 15.78 & 609.1608 & 0.2 \\
\hline
\end{tabular}

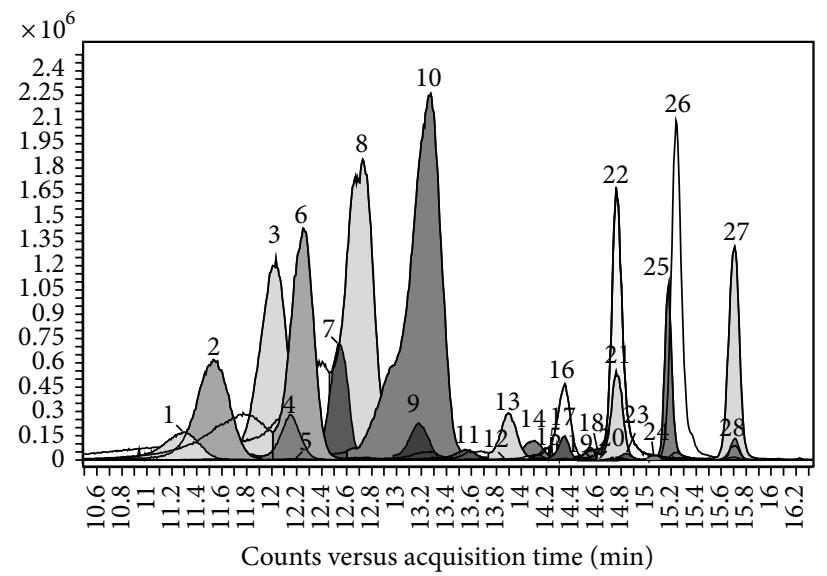

FIGURE 4: Extracted ion chromatograms of $\mathrm{M}^{+\bullet}$ ion signals of anthocyanins identified in the UHPLC/QTOF analysis of Clinton grape extract. 
<smiles>OCC1OC(Oc2cc(O)cc(/C=C/c3ccc(O)c(O)c3)c2)C(O)C(O)[C@@H]1O</smiles>

1

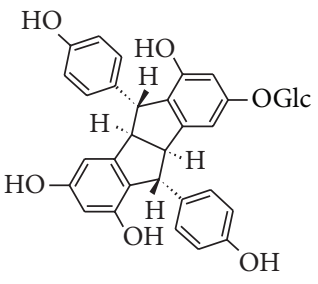

5
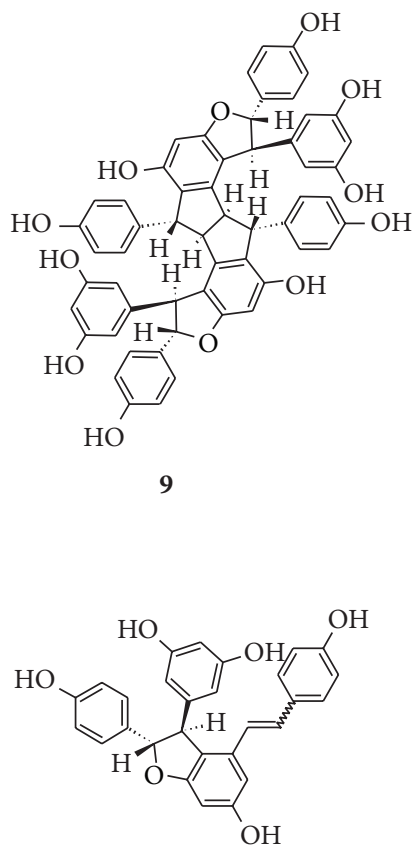

13<smiles>OCC1OC(Oc2cc(O)cc(/C=C/c3ccc(O)cc3)c2)C(O)C(O)C1O</smiles>

2<smiles>Oc1ccc(C=C2c3cc(O)cc(O)c3[C@@H](c3ccc(O)cc3)[C@H]2c2ccc(O)cc2)cc1</smiles>

6

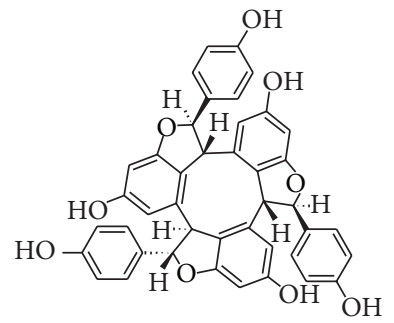

10

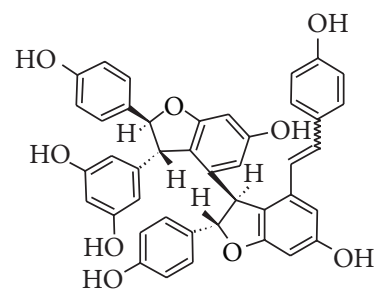

14<smiles>Oc1cc(O)cc(C=Cc2ccc(O)c(O)c2)c1</smiles><smiles>Oc1ccc([C@H]2c3cc(O)cc(O)c3[C@@H](c3ccc(O)cc3)[C@H]2c2ccc(O)cc2O)cc1</smiles>

4<smiles>Oc1ccc(/C=C/c2cc(O)cc(O)c2)cc1</smiles>

7

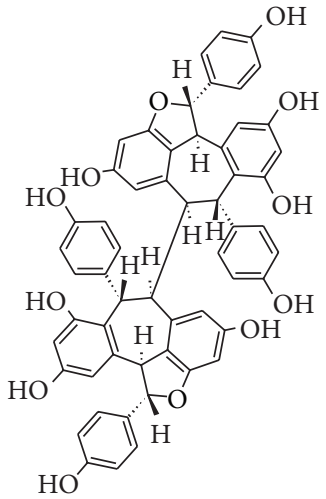

8

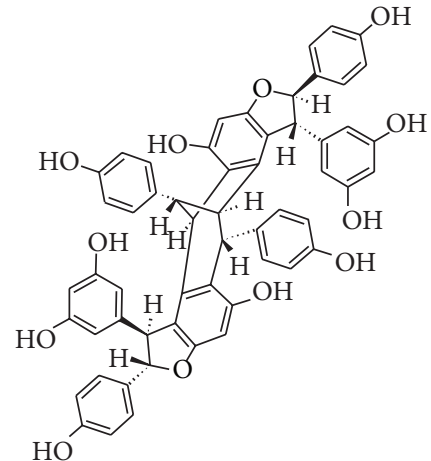

11<smiles></smiles>

12<smiles>Oc1ccc(C2Oc3ccc(C=Cc4cc(O)cc(O)c4)cc3C2c2ccc(O)cc2)cc1</smiles>

15<smiles>COc1ccc(/C=C/c2cc(O)cc(O)c2)cc1</smiles>

16

FIGURE 5: Principal stilbenes identified in vine tissues. (1) $E$ - and $Z$-astringin, (2) $E$ - and $Z$-piceid, (3) piceatannol, (4) pallidol, (5) pallidol3-O-glucoside, (6) parthenocissin A, (7) trans-resveratrol, (8) hopeaphenol, (9) ampelopsin $\mathrm{H},(\mathbf{1 0}) \alpha$-viniferin, (11) vaticanol C isomer, (12) caraphenol B, (13) $E$ - and $Z$ - $\varepsilon$-viniferin, (14) $E$ - and $Z$-miyabenol C, (15) $E$ - and $Z$ - $\delta$-viniferin, and (16) trans-resveratrol- $4^{\prime}$-methyl ether.

precursor ions at $\mathrm{m} / \mathrm{z} 905.260$ were identified in grape for the first time: hopeaphenol (previously found in red wine [54]) and ampelopsin H/vaticanol C-like/isohopeaphenol (compounds previously found in $V$. vinifera leaves[16]).

\section{Conclusions}

High-resolution MS coupled to suspect screening analysis is effective in the study of grape metabolomics. With two analyses (positive and negative ionization modes) several 
TABle 3: Stilbene $[\mathrm{M}-\mathrm{H}]^{-}$ions identified in Primitivo grape extract. Identification scores calculated with respect to the theoretical mass are reported. Numbers correspond to the peaks of chromatogram in Figure 6.

\begin{tabular}{|c|c|c|c|c|c|c|}
\hline \multirow[b]{2}{*}{ Peak } & \multirow[b]{2}{*}{ Stilbene compounds } & \multirow[b]{2}{*}{ Formula } & \multicolumn{4}{|c|}{$[\mathrm{M}-\mathrm{H}]^{-}$} \\
\hline & & & Rt (min) & $\begin{array}{l}\text { Experimental } \\
\qquad \mathrm{m} / z\end{array}$ & $\begin{array}{c}\text { Theoretical } \\
m / z\end{array}$ & Error (ppm) \\
\hline 1 & E-Astringin (piceatannol glucoside) & $\mathrm{C}_{20} \mathrm{H}_{21} \mathrm{O}_{9}$ & 13.94 & 405.1198 & 405.1191 & 1.7 \\
\hline 2 & E-Piceid & $\mathrm{C}_{20} \mathrm{H}_{21} \mathrm{O}_{8}$ & 14.94 & 389.1249 & 389.1242 & 1.8 \\
\hline 3 & $Z$-Astringin & $\mathrm{C}_{20} \mathrm{H}_{21} \mathrm{O}_{9}$ & 15.12 & 405.1190 & 405.1191 & -0.2 \\
\hline 4 & Piceatannol & $\mathrm{C}_{14} \mathrm{H}_{11} \mathrm{O}_{4}$ & 15.92 & 243.0666 & 243.0663 & 1.2 \\
\hline 5 & Z-Piceid & $\mathrm{C}_{20} \mathrm{H}_{21} \mathrm{O}_{8}$ & 15.97 & 389.1244 & 389.1242 & 0.5 \\
\hline 6 & Dimer 1 (pallidol) & $\mathrm{C}_{28} \mathrm{H}_{21} \mathrm{O}_{6}$ & 16.50 & 453.1347 & 453.1344 & 0.7 \\
\hline 7 & Pallidol-3-O-glucoside & $\mathrm{C}_{34} \mathrm{H}_{31} \mathrm{O}_{11}$ & 17.01 & 615.1869 & 615.1872 & -0.5 \\
\hline 8 & Dimer 2 & $\mathrm{C}_{28} \mathrm{H}_{21} \mathrm{O}_{6}$ & 17.16 & 453.1345 & 453.1344 & 0.2 \\
\hline 9 & trans-Resveratrol & $\mathrm{C}_{14} \mathrm{H}_{11} \mathrm{O}_{3}$ & 17.29 & 227.0716 & 227.0714 & 0.9 \\
\hline 10 & Caraphenol B & $\mathrm{C}_{28} \mathrm{H}_{21} \mathrm{O}_{7}$ & 17.91 & 469.1292 & 469.1293 & -0.2 \\
\hline 11 & Tetramer 1 & $\mathrm{C}_{56} \mathrm{H}_{41} \mathrm{O}_{12}$ & 18.10 & 905.2602 & 905.2604 & -0.2 \\
\hline 12 & Tetramer 2 & $\mathrm{C}_{56} \mathrm{H}_{41} \mathrm{O}_{12}$ & 18.49 & 905.2607 & 905.2604 & 0.3 \\
\hline 13 & Dimer 3 ( $Z$ - $\varepsilon$-viniferin $)$ & $\mathrm{C}_{28} \mathrm{H}_{21} \mathrm{O}_{6}$ & 18.61 & 453.1346 & 453.1344 & 0.4 \\
\hline 14 & 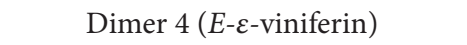 & $\mathrm{C}_{28} \mathrm{H}_{21} \mathrm{O}_{6}$ & 18.81 & 453.1346 & 453.1344 & 0.4 \\
\hline 15 & Trimer 1 (Z-miyabenol C) & $\mathrm{C}_{42} \mathrm{H}_{31} \mathrm{O}_{9}$ & 18.84 & 679.1976 & 679.1974 & 0.3 \\
\hline 16 & Trimer 2 (E-miyabenol C) & $\mathrm{C}_{42} \mathrm{H}_{31} \mathrm{O}_{9}$ & 18.93 & 679.1977 & 679.1974 & 0.4 \\
\hline 17 & Dimer 5 ( $\delta$-viniferin $)$ & $\mathrm{C}_{28} \mathrm{H}_{21} \mathrm{O}_{6}$ & 19.56 & 453.1342 & 453.1344 & -0.4 \\
\hline
\end{tabular}

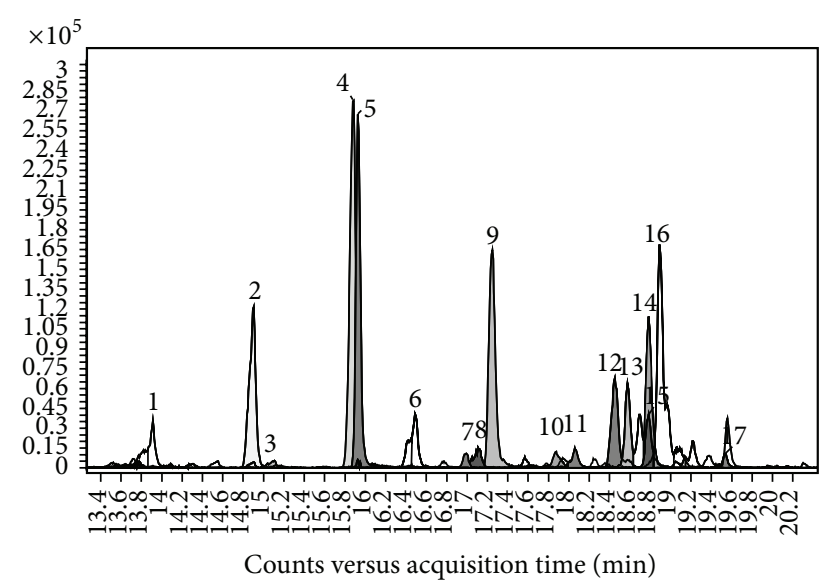

FIGURE 6: Extracted ion chromatograms of stilbene derivative [M$\mathrm{H}]^{-}$ion signals identified in UHPLC/QTOF analysis of Primitivo grape extract.

hundred grape polyphenols are identified, and four flavonols and some grape resveratrol trimers and tetramers were found in grape for the first time.

Main difficulty of the method was the construction of the database specific for grape and wine which required relevant time and an accurate data collection. On the other hand, advantage of this method is that by increasing the studied samples the database can be expanded.

Despite the fact that GrapeMetabolomics is a database specific for the enological field a similar approach can be potentially applied to metabolomics of varieties of other plant species.

\section{Conflict of Interests}

The authors declare that there is no conflict of interests regarding the publication of this paper.

\section{References}

[1] R. Flamini, "Recent applications of mass spectrometry in the study of grape and wine polyphenols," ISRN Spectroscopy, vol. 2013, Article ID 813563, 45 pages, 2013.

[2] N. Castillo-Muñoz, S. Gómez-Alonso, E. García-Romero, and I. Hermosín-Gutiérrez, "Flavonol profiles of Vitis vinifera red grapes and their single-cultivar wines," Journal of Agricultural and Food Chemistry, vol. 55, no. 3, pp. 992-1002, 2007.

[3] N. Castillo-Muñoz, S. Gómez-Alonso, E. García-Romero, M. U. Gómez, H. A. Velders, and I. Hermosín-Gutiérrez, "Flavonol 3$O$-glycosides series of Vitis vinifera Cv. Petit Verdot red wine grapes," Journal of Agricultural and Food Chemistry, vol. 57, no. 1, pp. 209-219, 2009.

[4] R. Flamini, "Mass spectrometry in grape and wine chemistry. Part I: polyphenols," Mass Spectrometry Reviews, vol. 22, no. 4, pp. 218-250, 2003.

[5] H. Wang, E. J. Race, and A. J. Shrikhande, "Characterization of anthocyanins in grape juices by ion trap liquid chromatography-mass spectrometry," Journal of Agricultural and Food Chemistry, vol. 51, no. 7, pp. 1839-1844, 2003.

[6] M. E. Camire, A. Chaovanalikit, M. P. Dougherty, and J. Briggs, "Blueberry and grape anthocyanins as breakfast cereal colorants," Journal of Food Science, vol. 67, no. 1, pp. 438-441, 2002.

[7] J. He and M. Monica Giusti, "Anthocyanins: natural colorants with health-promoting properties," Annual Review of Food Science and Technology, vol. 1, no. 1, pp. 163-187, 2010. 
[8] V. Hong and R. E. Wrolstad, "Characterization of anthocyanincontaining colorants and fruit juices by HPLC/photodiode array detection," Journal of Agricultural and Food Chemistry, vol. 38, no. 3, pp. 698-708, 1990.

[9] M. de Rosso, L. Tonidandel, R. Larcher et al., "Study of anthocyanic profiles of twenty-one hybrid grape varieties by liquid chromatography and precursor-ion mass spectrometry," Analytica Chimica Acta, vol. 732, pp. 120-129, 2012.

[10] M. de Rosso, L. Tonidandel, R. Larcher et al., "Identification of new flavonols in hybrid grapes by combined liquid chromatography-mass spectrometry approaches," Food Chemistry, vol. 163, no. 1, pp. 244-251, 2014.

[11] X. Vitrac, A. Bornet, R. Vanderlinde et al., "Determination of stilbenes ( $\delta$-viniferin, trans-astringin, trans-piceid, cis- and trans-resveratrol, $\mathcal{E}$-viniferin) in Brazilian wines," Journal of Agricultural and Food Chemistry, vol. 53, no. 14, pp. 5664-5669, 2005.

[12] L. Bavaresco, E. Cantù, M. Fregoni, and M. Trevisan, "Constitutive stilbene contents of grapevine cluster stems as potential source of resveratrol in wine," Vitis, vol. 36, no. 3, pp. 115-118, 1997.

[13] P. Waffo-Teguo, D. Lee, M. Cuendet, J.-M. Mërillon, J. M. Pezzuto, and A. Douglas Kinghorn, "Two new stilbene dimer glucosides from grape (Vitis vinifera) cell cultures," Journal of Natural Products, vol. 64, no. 1, pp. 136-138, 2001.

[14] R. H. Cichewicz, S. A. Kouzi, and M. T. Hamann, "Dimerization of resveratrol by the grapevine pathogen Botrytis cinerea," Journal of Natural Products, vol. 63, no. 1, pp. 29-33, 2000.

[15] M. Sbaghi, P. Jeandet, R. Bessis, and P. Leroux, "Degradation of stilbene-type phytoalexins in relation to the pathogenicity of Botrytis cinerea to grapevines," Plant Pathology, vol. 45, no. 1, pp. 139-144, 1996.

[16] F. Mattivi, U. Vrhovsek, G. Malacarne et al., "Profiling of resveratrol oligomers, important stress metabolites, accumulating in the leaves of hybrid Vitis vinifera (Merzling $\times$ Teroldego) genotypes infected with Plasmopara viticola," Journal of Agricultural and Food Chemistry, vol. 59, no. 10, pp. 5364-5375, 2011.

[17] A. D. Pawlus, R. Sahli, J. Bisson et al., "Stilbenoid profiles of canes from Vitis and Muscadinia species," Journal of Agricultural and Food Chemistry, vol. 61, no. 3, pp. 501-511, 2013.

[18] M. Jang, L. Cai, G. O. Udeani et al., "Cancer chemopreventive activity of resveratrol, a natural product derived from grapes," Science, vol. 275, no. 5297, pp. 218-220, 1997.

[19] L.-M. Hung, J.-K. Chen, S.-S. Huang, R.-S. Lee, and M.-J. Su, "Cardioprotective effect of resveratrol, a natural antioxidant derived from grapes," Cardiovascular Research, vol. 47, no. 3, pp. 549-555, 2000.

[20] E. N. Frankel, A. L. Waterhouse, and J. E. Kinsella, "Inhibition of human LDL oxidation by resveratrol," The Lancet, vol. 341, no. 8852, pp. 1103-1104, 1993.

[21] L. Frémont, L. Belguendouz, and S. Delpal, "Antioxidant activity of resveratrol and alcohol-free wine polyphenols related to LDL oxidation and polyunsaturated fatty acids," Life Sciences, vol. 64, no. 26, pp. 2511-2521, 1999.

[22] A. A. E. Bertelli, L. Giovannini, D. Giannessi et al., "Antiplatelet activity of synthetic and natural resveratrol in red wine," International Journal of Tissue Reactions, vol. 17, no. 1, pp. 1-3, 1995.

[23] C. R. Pace-Asciak, S. E. Hahn, E. P. Diamandis, G. Soleas, and D. M. Goldberg, "The red wine phenolics trans-resveratrol and quercetin block human platelet aggregation and eicosanoid synthesis: implications for protection against coronary heart disease," Clinica Chimica Acta, vol. 235, no. 2, pp. 207-219, 1995.

[24] L. Bavaresco, F. Mattivi, M. de Rosso, and R. Flamini, "Effects of elicitors, viticultural factors, and enological practices on resveratrol and stilbenes in Grapevine and Wine," Mini-Reviews in Medicinal Chemistry, vol. 12, no. 13, pp. 1366-1381, 2012.

[25] R. L. Geahlen and J. L. McLaughlin, "Piceatannol $\left(3,4,3^{\prime}, 5^{\prime}\right.$ tetrahydroxy-trans-stilbene) is a naturally occurring proteintyrosine kinase inhibitor," Biochemical and Biophysical Research Communications, vol. 165, no. 1, pp. 241-245, 1989.

[26] M. Swanson-Mungerson, M. Ikeda, L. Lev, R. Longnecker, and T. Portis, "Identification of latent membrane protein 2A (LMP2A) specific targets for treatment and eradication of Epstein-Barr virus (EBV)-associated diseases," Journal of Antimicrobial Chemotherapy, vol. 52, no. 2, pp. 152-154, 2003.

[27] M. Larrosa, F. A. Tomás-Barberán, and J. C. Espín, “The grape and wine polyphenol piceatannol is a potent inducer of apoptosis in human SK-Mel-28 melanoma cells," European Journal of Nutrition, vol. 43, no. 5, pp. 275-284, 2004.

[28] R. Di Stefano and R. Flamini, "High performance liquid chromatography analysis of grape and wine polyphenols," in Hyphenated Techniques in Grape \& Wine Chemistry, pp. 33-80, John Wiley \& Sons, Hoboken, NJ, USA, 2008.

[29] R. Flamini and M. de Rosso, "Polyphenols analysis by liquidmass spectrometry," in Hyphenated Techniques in Grape \& Wine Chemistry, pp. 81-128, John Wiley \& Sons, Hoboken, NJ, USA, 2008.

[30] M. de Rosso, A. Panighel, A. D. Vedova, L. Stella, and R. Flamini, "Changes in chemical composition of a red wine aged in acacia, cherry, chestnut, mulberry, and oak wood barrels," Journal of Agricultural and Food Chemistry, vol. 57, no. 5, pp. 1915-1920, 2009.

[31] L. Stella, M. De Rosso, A. Panighel, A. Dalla Vedova, R. Flamini, and P. Traldi, "Collisionally induced fragmentation of $[\mathrm{M}-\mathrm{H}]-$ species of resveratrol and piceatannol investigated by deuterium labelling and accurate mass measurements," Rapid Communications in Mass Spectrometry, vol. 22, no. 23, pp. 38673872, 2008.

[32] S. Pati, M. T. Liberatore, G. Gambacorta, D. Antonacci, and E. la Notte, "Rapid screening for anthocyanins and anthocyanin dimers in crude grape extracts by high performance liquid chromatography coupled with diode array detection and tandem mass spectrometry," Journal of Chromatography A, vol. 1216, no. 18, pp. 3864-3868, 2009.

[33] D. Favretto and R. Flamini, "Application of electrospray ionization mass spectrometry to the study of grape anthocyanins," American Journal of Enology and Viticulture, vol. 51, no. 1, pp. 55-64, 2000.

[34] R. Flamini, M. de Rosso, A. Smaniotto et al., "Fast analysis of isobaric grape anthocyanins by chip-liquid chromatography/mass spectrometry," Rapid Communications in Mass Spectrometry, vol. 23, no. 18, pp. 2891-2896, 2009.

[35] P. Arapitsas, M. Scholz, U. Vrhovsek et al., "A metabolomic approach to the study of wine micro-oxygenation," PLoS ONE, vol. 7, no. 5, Article ID e37783, 2012.

[36] A. Cuadros-Inostroza, P. Giavalisco, J. Hummel, A. Eckardt, L. Willmitzer, and H. Peña-Cortés, "Discrimination of wine attributes by metabolome analysis," Analytical Chemistry, vol. 82, no. 9, pp. 3573-3580, 2010.

[37] L. Vaclavik, O. Lacina, J. Hajslova, and J. Zweigenbaum, "The use of high performance liquid chromatography-quadrupole 
time-of-flight mass spectrometry coupled to advanced data mining and chemometric tools for discrimination and classification of red wines according to their variety," Analytica Chimica Acta, vol. 685, no. 1, pp. 45-51, 2011.

[38] M. Krauss, H. Singer, and J. Hollender, "LC-high resolution MS in environmental analysis: from target screening to the identification of unknowns," Analytical and Bioanalytical Chemistry, vol. 397, no. 3, pp. 943-951, 2010.

[39] R. Flamini, M. de Rosso, F. de Marchi et al., "An innovative approach to grape metabolomics: stilbene profiling by suspect screening analysis," Metabolomics, vol. 9, no. 6, pp. 1243-1253, 2013.

[40] S. Kueger, D. Steinhauser, L. Willmitzer, and P. Giavalisco, "High-resolution plant metabolomics: from mass spectral features to metabolites and from whole-cell analysis to subcellular metabolite distributions," The Plant Journal, vol. 70, no. 1, pp. 39-50, 2012.

[41] T. R. Sana, J. C. Roark, X. Li, K. Waddell, and S. M. Fischer, "Molecular formula and METLIN personal metabolite database matching applied to the identification of compounds generated by LC/TOF-MS," Journal of Biomolecular Techniques, vol. 19, no. 4, pp. 258-266, 2008.

[42] K. Hanhineva, I. Rogachev, H. Kokko et al., "Non-targeted analysis of spatial metabolite composition in strawberry (Fragaria $\times$ ananassa) flowers," Phytochemistry, vol. 69, no. 13, pp. 24632481, 2008.

[43] M. Brown, W. B. Dunn, P. Dobson et al., "Mass spectrometry tools and metabolite-specific databases for molecular identification in metabolomics," Analyst, vol. 134, no. 7, pp. 1322-1332, 2009.

[44] R. C. H. De Vos, S. Moco, A. Lommen, J. J. B. Keurentjes, R. J. Bino, and R. D. Hall, "Untargeted large-scale plant metabolomics using liquid chromatography coupled to mass spectrometry," Nature Protocols, vol. 2, no. 4, pp. 778-791, 2007.

[45] A. Scalbert, L. Brennan, O. Fiehn et al., "Mass-spectrometrybased metabolomics: limitations and recommendations for future progress with particular focus on nutrition research," Metabolomics, vol. 5, no. 4, pp. 435-458, 2009.

[46] A. I. Romero-Pérez, M. Ibern-Gómez, R. M. LamuelaRaventós, and M. C. de La Torre-Boronat, "Piceid, the major resveratrol derivative in grape juices," Journal of Agricultural and Food Chemistry, vol. 47, no. 4, pp. 1533-1536, 1999.

[47] B. Baderschneider and P. Winterhalter, "Isolation and characterization of novel stilbene derivatives from Riesling wine," Journal of Agricultural and Food Chemistry, vol. 48, no. 7, pp. 2681-2686, 2000.

[48] X. Vitrac, C. Castagnino, P. Waffo-Téguo et al., "Polyphenols newly extracted in red wine from Southwestern France by centrifugal partition chromatography," Journal of Agricultural and Food Chemistry, vol. 49, no. 12, pp. 5934-5938, 2001.

[49] R. Pezet, C. Perret, J. B. Jean-Denis, R. Tabacchi, K. Gindro, and $\mathrm{O}$. Viret, " $\delta$-viniferin, a resveratrol dehydrodimer: one of the major stilbenes synthesized by stressed grapevine leaves," Journal of Agricultural and Food Chemistry, vol. 51, no. 18, pp. 5488-5492, 2003.

[50] T. Püssa, J. Floren, P. Kuldkepp, and A. Raal, "Survey of grapevine Vitis vinifera stem polyphenols by liquid chromatography-diode array detection-tandem mass spectrometry," Journal of Agricultural and Food Chemistry, vol. 54, no. 20, pp. 74887494, 2006.

[51] J. B. Jean-Denis, R. Pezet, and R. Tabacchi, "Rapid analysis of stilbenes and derivatives from downy mildew-infected grapevine leaves by liquid chromatography-atmospheric pressure photoionisation mass spectrometry," Journal of Chromatography A, vol. 1112, no. 1-2, pp. 263-268, 2006.

[52] A. D. Pawlus, P. Waffo-Téguo, J. Shaver, and J.-M. Mérillon, "Stilbenoid chemistry from wine and the genus Vitis, a review," Journal International des Sciences de la Vigne et du Vin, vol. 46, no. 2, pp. 57-111, 2012.

[53] Y. Takaya, K. Terashima, K.-X. Yan, and M. Niwa, “(+)-Viniferol $\mathrm{D}$, a new stilbenetrimer from the stem of Vitis vinifera 'Kyohou," Heterocycles, vol. 60, no. 6, pp. 1433-1439, 2003.

[54] H. A. Guebailia, K. Chira, T. Richard et al., "Hopeaphenol: the first resveratrol tetramer in wines from North Africa," Journal of Agricultural and Food Chemistry, vol. 54, no. 25, pp. 9559-9564, 2006.

[55] F. Mazzotti, L. DiDonna, H. Benabdelkamel, B. Gabriele, A. Napoli, and G. Sindona, "The assay of pterostilbene in spikedmatrices by liquid chromatography tandemmass spectrometry and isotope dilution method," Journal of Mass Spectrometry, vol. 45, no. 4, pp. 358-363, 2010.

[56] M. Adrian, P. Jeandet, A. C. Douillet-Breuil, D. Levite, S. Debord, and R. Bessis, "Assay of resveratrol and derivative stilbenes in wines by direct injection high performance liquid chromatography," American Journal of Enology and Viticulture, vol. 51, no. 1, pp. 37-41, 2000.

[57] M. Adrian, P. Jeandet, A. C. Douillet-Breuil, L. Tesson, and R. Bessis, "Stilbene content of mature Vitis vinifera berries in response to UV-C elicitation," Journal of Agricultural and Food Chemistry, vol. 48, no. 12, pp. 6103-6105, 2000.

[58] A.-C. Douillet-Breuil, P. Jeandet, M. Adrian, and R. Bessis, "Changes in the phytoalexin content of various Vitis spp. in response to ultraviolet C elicitation," Journal of Agricultural and Food Chemistry, vol. 47, no. 10, pp. 4456-4461, 1999.

[59] V. Jerkovic, F. Nguyen, S. Nizet, and S. Collin, "Combinatorial synthesis, reversed-phase and normal-phase high-performance liquid chromatography elution data and liquid chromatography/positive atmospheric pressure chemical ionization tandem mass spectra of methoxylated and glycosylated resveratrol analogues," Rapid Communications in Mass Spectrometry, vol. 21, no. 15, pp. 2456-2466, 2007. 

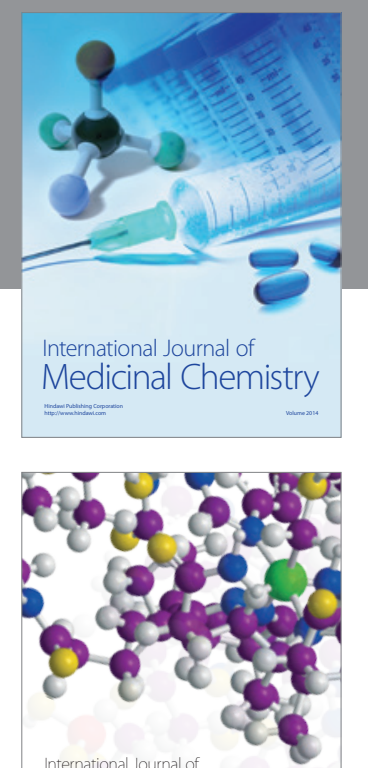

\section{Carbohydrate} Chemistry

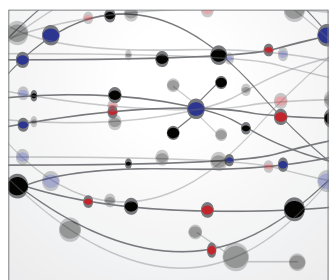

The Scientific World Journal
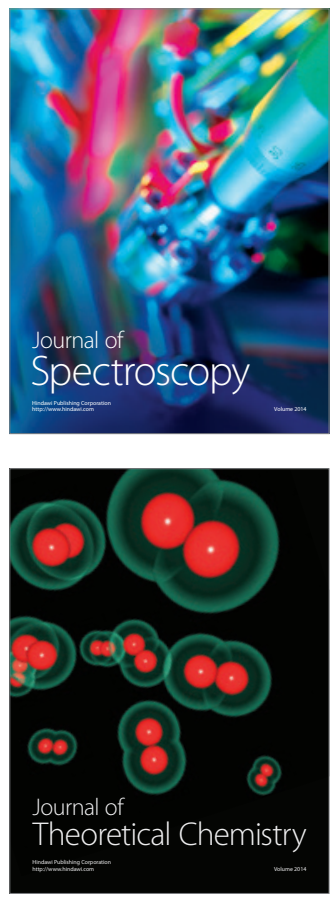
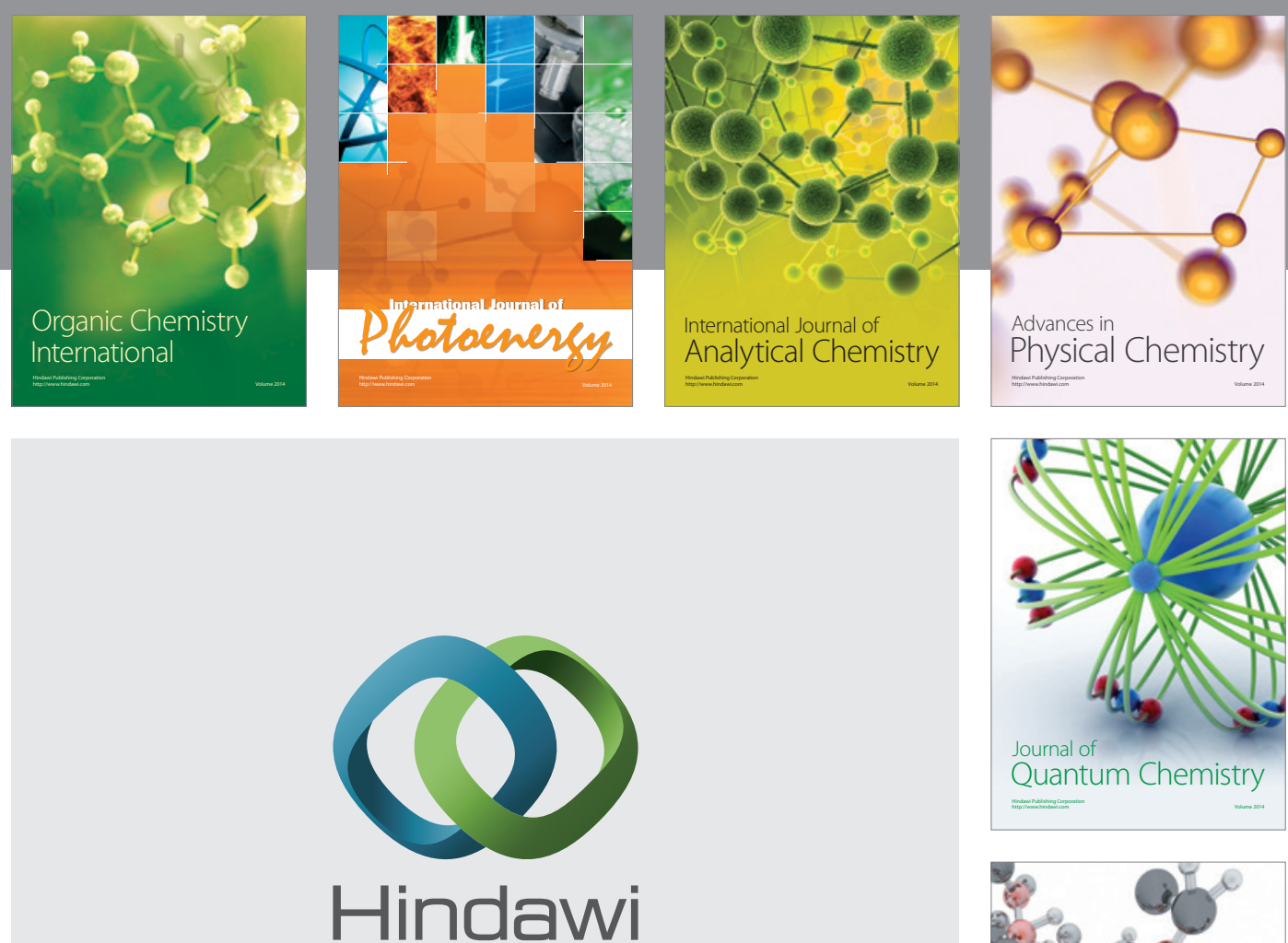

Submit your manuscripts at

http://www.hindawi.com

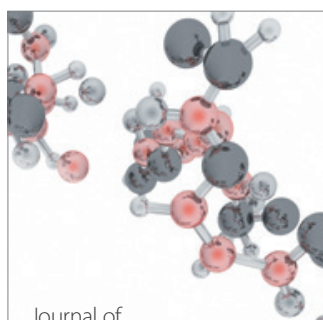

Analytical Methods

in Chemistry

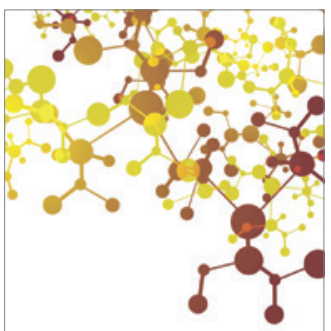

Journal of

Applied Chemistry

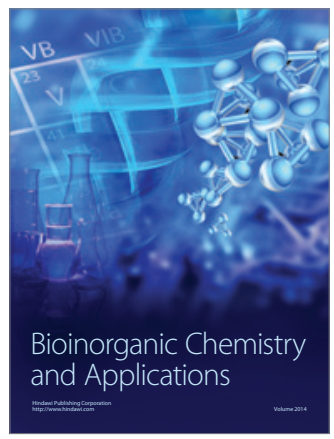

Inorganic Chemistry
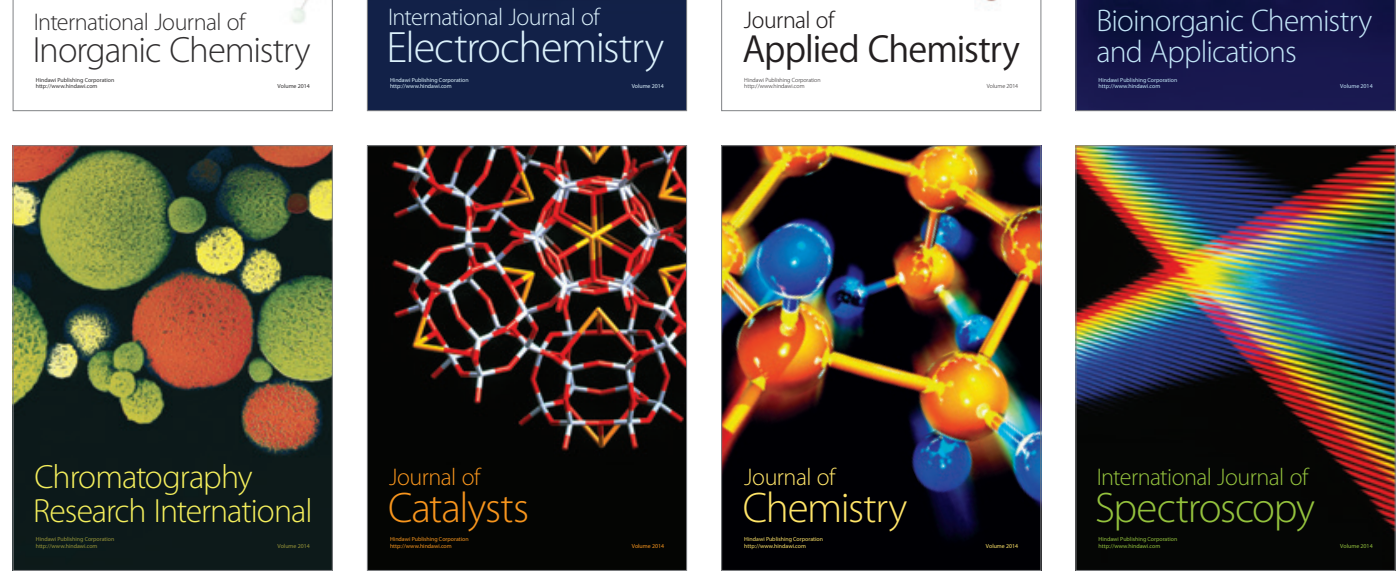